Learning analytics in education: Literature review and case examples from vocational education

Egle Gedrimiene

Faculty of Education, University of Oulu, Oulu, Finland

egle.gedrimiene@oulu.fi

Anni Silvola

Faculty of Education, University of Oulu, Oulu, Finland

anni.silvola@oulu.fi

Jouni Pursiainen

Department of Chemistry, University of Oulu, Oulu, Finland

jouni.pursiainen@oulu.fi

Jarmo Rusanen

The Geography Research Unit of the University of Oulu, University of Oulu, Oulu, Finland jarmo.rusanen@oulu.fi

Hanni Muukkonen

Faculty of Education, University of Oulu, Oulu, Finland

hanni.muukkonen@oulu.fi 


\title{
Learning analytics in education: Literature review and case examples from vocational education
}

\begin{abstract}
Vocational education and training (VET) remain overlooked in learning analytics (LA) research. This systematic literature review, using four databases and other sources, was carried out by analyzing selected 60 articles (2012-2017) to study the levels and stages of education that the reviewed LA literature examined. The review indicated that most of the analyzed papers focused on the course level, followed by student and institution levels in higher education. Few empirical studies have addressed LA use during the VET stage, particularly at the governmental level. We also considered ethical concerns and recommendations for further LA development in VET. It is suggested to use LA in knowledge transfer and integration between the classroom and workplace.
\end{abstract}

Keywords: learning analytics; vocational education; educational technology; ethics;

\section{Introduction}

Dropouts, rising immigration rates, new demands for workforce competencies, digitalization, and 
economic challenges require new innovative approaches to secure students' success. Therefore, interest in learning analytics (LA) has been growing, and several studies have examined LA possibilities in higher education. However, vocational learning involves workplace learning and assessment, adding another context in addition to the institutional setting in vocational education and training (VET). VET is an important part of the lifelong learning system in Europe, with an average of $50 \%$ of young Europeans ages 15-19 participating in VET (European Commission, 2012). However, scientific research on the topic of educational-technology use in VET contexts is lacking. This paper aims to address this gap by analyzing LA possibilities and challenges regarding specific VET needs through available research in the context of VET.

\section{LA definition and development}

Learning analytics is the measurement, collection, analysis, and reporting of data about learners and their contexts to understand and optimize learning and the environments in which it occurs (Siemens, 2013), as well as assess educational communities' behavior (Larusson \& White, 2014). Online learners leave behind data traces, and LA can gather this data from different sources and learner activities, then analyze and provide meaningful insights and visualizations for institutions, teachers, and learners. Business intelligence has made a major impact on LA development by bringing tracking, collection, and data-analysis methods into the educational context (Bienkowski, Feng, \& Means, 2012; Ferguson, 2012). Big-data sets' availability, online learning on a large scale, and political concerns about educational standards have elicited the need for LA (Ferguson, 2012), a multidisciplinary field connecting computer science, educational research, and statistics. 


\section{VET context}

VET is a key element of lifelong learning systems, equipping people with the knowledge, skills, and competencies required for particular occupations and in the general labor market (European Commission, 2015). VET's role is to increase and maintain the population's vocational skills and competence levels, develop the world of work, respond to the work realm's skill demands, promote employment, increase entrepreneurship, and support lifelong learning and professional growth (Finnish National Agency for Education, 2017). Vocational institutions' populations are very diverse (Juutilainen \& Räty, 2017), as they serve students from almost all age groups (e.g., teens, young adults, adult learners) and cultural, ethnic, and socioeconomic backgrounds, with varying linguistic and academic abilities. VET also combines learning academic skills on campus with practice-based skills needed in authentic contexts (Hansen, Netteland, \& Wasson, 2016).

On-the-job training could be viewed as a method to reduce exclusion and non-completion of education (Honkonen, 2017), and it becomes critical when entry-level jobs are scarce, and a high level of theoretical and practical expertise is needed to enter the world of work. In Finland, some 50 percent of students finishing their basic education continue their studies in VET (Laukia, 2017, p. 19), but significant differences in European countries exist (European Commission, 2012).

VET's importance differs depending on the context. Over 80 percent of students with special-education needs attend vocational schools in Finland (Juutilainen \& Räty, 2017, from Bureau of Statistics), and VET provides special-needs students with an opportunity to obtain the same qualifications as other students. It also could be a primary option for immigrants to develop needed competencies in their new country, as well as provide a transition to help reintegrate 
released convicts back into the work realm and community after imprisonment (Giles, Le, Allan, Lees, Larsen, \& Bennett, 2007).

\section{Previous reviews' focus}

Previously published LA reviews have demonstrated a high level of interest and expectations, focusing on drivers and challenges (Ferguson, 2012), as well as taking a more specific approach from the perspective of education in computer science (Ihantola et al., 2015), the role of different conceptions of learning (Ruiz-Calleja, Prieto, Ley, Rodriguez-Triana, \& Dennerlein, 2017), or data gathering and analysis methods used in this field (Leitner, Khalil, \& Ebner, 2017; Papamitsiou \& Economides, 2014). However, studies analyzed in these reviews have not addressed VET to such an extent that we could identify what the LA characteristics are in VET and which issues should be considered in future LA design in the VET context. "Transfer of knowledge and skills between school and practice and vice versa is one central aim of VET" (Isacsson, 2017, p. 45). Thus, not enough research exists on the possibilities of using LA to transfer knowledge and competencies between practice and theory, school and workplace. This review aims to draw attention to the possibilities and specific VET needs in the context of LA.

\section{Problem definition}

LA is not equally acknowledged or used in other fields outside of higher education (Drachsler \& Greller, 2012). Based on three drivers of LA — big data, online learning, and political concernsFerguson (2012) has identified three different target LA audiences or interest groups: governments; educational institutions; and teachers - defined as focus levels. Each particular interest group determines how the information is analyzed, i.e., how researchers gather data, 
present findings, act on these findings, and refine their modules (Ferguson, 2012). To better understand different contexts in which LA could be used, and how different LA applications support learning and education, we analyzed how extant LA literature addresses these levels. A systematic literature review was carried out to address the following questions:

(1) Which levels and stages of education did the reviewed LA literature focus on?

(2) How was LA used at different levels?

(3) How has LA been used in different VET contexts?

(4) What ethical concerns have been raised in relation to LA use in VET?

\section{Methodology}

The systematic literature review was conducted by following the procedures of Cooper $\&$ Hedges (2009) for research synthesis. A PRISMA checklist (Moher, Liberati, Tetzlaff, Altman, \& The PRISMA Group, 2009) was used during search retrieval, as well as article selection and inclusion in the review.

\section{Search retrieval and selection criteria}

ProQuest, EBSCO, Primo Central, and the Finnish database Finna were used for the searches. Google Scholar was used to ensure identification of key literature in the field.

The following search words were used in various combinations: Learning analytics AND vocational education OR vocational OR technical education (as a synonym for vocational education) OR work training OR special education, vocational education, and big data. Searches were extended later, with search-word combinations learning analytics AND challenges and learning analytics AND data. 
The searches yielded 309 articles, with another 48 hand-picked from database recommendations, the Journal of Learning Analytics, and other sources. Duplicates were removed, and the first screening of the articles was done based on the following inclusion criteria:

- The article focused on LA

- LA was used in an educational or work-training context, i.e., VET

- The article was published between 2012 and 2017

- The paper was peer-reviewed

Altogether, 84 articles were chosen for further reading and analysis, with 60 comprising empirical studies, reviews, conference papers, book chapters, and framework articles chosen for the final analysis. Only three articles focused specifically on LA applications in VET. Thus, an approach was selected to provide an analysis of existing data and offer insights into possible VET applications.

\section{Data analysis: Coding of LA characteristics}

The focus level in LA was examined in each article. Categories were built on the earlier division by Ferguson (2012). Extending on these three target-audience levels (Ferguson, 2012), we further separated teacher and student levels to provide more detailed attention to the user needs demonstrated in previous studies, better reflect differences of LA applications, build stronger connections with learning-sciences research, and investigate factors that promote individual learning (Gasevic, Dawson, \& Siemens, 2015; Ferguson 2012). Thus, in our analysis, a teacherlevel article provides feedback to a teacher about students' progress in learning, and a studentlevel article focuses on the tools that provide feedback to students. Although the same data can be used for several purposes, the coding category was assigned depending on whom the paper 
was aimed at, as well as who was receiving feedback as a final result of the process. The following coding categories were assigned to the articles: 1-governmental; 2- institutional; 3 course/teacher; 4- individual student; 5- student, course, institution, and governmental levels combined; and 6-researchers/vendors (included during the analysis process).

Two researchers coded the articles separately, with 40 articles $(66.7 \%)$ out of 60 coded consistently. Disagreements were negotiated by going through the remaining 20 articles again and coding them together.

Education stage (e.g., higher education, high school, vocational education, primary education) was determined to better understand how LA literature has developed during the 2012-2017 period.

\section{Results}

The analyzed articles covered all education levels, with most (32) focusing on the course or teacher level, 23 on the student level, and 19 on the institution level, with six focusing on the governmental level and five on researchers' interests (see Table 1).

Seven articles focused on all levels. Because the same data and feedback can be generated for several agents, some levels overlapped, which could be explained by the groups' overlapping interests. The groups that overlapped the most were those coexisting near each other, e.g., students and teachers or course leader/teacher and school administration/institution. This result is supported by the notion that information flows between stakeholders (Greller \& Drachsler, 2012).

Table 1. Overview of the reviewed papers in terms of focus level (1-government; 2-institution; 3course; 4-individual; 5-government, institution, course, individual; and 6-research) and education 
stage $(\mathrm{h}$ - higher education, $\mathrm{v}$ - vocational education, $\mathrm{s}$ - secondary, $\mathrm{p}$ - primary, $\mathrm{ns}$ - not specified).

The analyzed VET articles focused on various levels, i.e., students, teachers/course, and institutions. Not a single article covered the governmental level from the VET perspective; however, the governmental-level focus could be expected to be similar to the one in higher education due to the hierarchical structure of educational governance.

Some articles directed their attention toward researchers or vendors' needs and could not be assigned to any of the individual levels, so another category was introduced to group these articles. However, this group of articles was not analyzed further in this paper, as we focused on education and vocational institutions.

Another challenge was noted while using this kind of categorization. Although some specific level was the target of the analysis in each article, there could be different beneficiaries for the same feedback, e.g., the teacher can get LA feedback and use it for professional development, as well as help struggling students simultaneously. Although two researchers coded the articles, the possibility of having a third researcher in the coding process would have increased the coding's reliability.

Education stage was determined for each article, with 24 papers focusing on higher education, three on VET specifically, and one containing data from vocational institutions together with higher education. Three publications addressed secondary education, and two addressed primary education. The small number of papers considering primary education is understandable, as little learning is done online in primary school, and considerable ethical obstacles exist when dealing with young students. It should be expected that parents would be 
included in the LA focus, as students' data also could be useful for parents of VET students who are under 18 years of age.

We observed that the articles on VET and LA were more recent, which could signify increasing interest in this topic. However, they are still underrepresented compared with higher education, with 31 articles not specifying education stage, suggesting that it could be used in various settings.

To sum up, we found these kinds of levels helpful in structuring LA papers and presenting further qualitative descriptions of typical LA use.

\section{LA use at different levels in the educational system and possible VET applications}

We present examples and describe qualitatively how LA could be used at the student, teacher, administrator, and government levels, considering specific VET characteristics.

Figure 1. Summary of LA possibilities that correspond to education-system levels.

\section{Governmental level}

LA provides data about students and schools that can be used to guide educational policy. Although no framework for data governance in LA exists (Elouazizi, 2014), it is considered to be functioning as a digital-policy instrument (Williamson, 2016), enabling comparisons between schools with similar student intakes from different regions, as well as comparisons of educational results using the national standard. Governments can use this information to improve and optimize their VET networks at national and regional levels. This currently remains a theoretical possibility. 


\section{Institutional level}

Educational institutions collect data about students' behavior to support knowledge-based decision making. It is expected that with the help of LA, education can become more effective, cost-efficient (Greller \& Drachsler, 2012), and accessible. However, according to a report summarizing data from eight different US schools using LA, only one reduced costs while simultaneously improving students' educational goals (Yarnall, Means, \& Wetzel, 2016).

It has been suggested that LA could improve secondary- and tertiary-level institutions' social services, in which a need exists to personalize students' learning paths and manage low resources to provide individual support. In recent years, student guidance counselling, special support, and welfare services in Finnish VET have started cultivating the idea that all teachers should be involved in supporting students' studies and career choices (Juutilainen \& Räty, 2017). This tendency could be assisted, with LA applications providing necessary information, timing and help in analyzing existing data registries.

Library systems could be improved by acquiring data on readers' activity, needs and interests; soliciting suggestions for book purchases based on the current library collection and future needs; making more personalized reading suggestions to students and teachers; and targeting students who need better reading habits (Boulden, 2015).

LA could help institutions better understand students' future employment prospects and promote better educational and vocational planning (Avella, Kerbritchi, Nunn, \& Kanai, 2016). For this, information needs to be available on actual post-educational employment status. Dropout rates and completion percentages also could be used for VET quality assurance (Saranpää, 2017). Some deeper insights might be gained by analyzing dropouts' information and taking preventive measures. However, LA technological development and constant institutional 
tracking of students do not lead automatically to better student outcomes. Student-centered and value-based pedagogical methods as well as meaningful learning experiences should be at the forefront of institutional planning, assisting with data only when needed.

\section{Course level}

Different LA applications can provide insights into what is occurring in the classroom, identify individual needs, provide targeted activities, and personalize the learning process (Ihantola et al., 2015). In virtual-learning environments, different supporting tools for teachers are created to present summaries, analyses, and visualizations of students' online participation and discussion activity (Van Leeuwen, Janssen, Erkens, \& Brekelmans, 2014). A typical way to visualize LA data is to present it on a teacher's dashboard to oversee class progress and keep track of individual learning processes. However, this requires that teachers develop data literacy. Teachers need to understand how to interpret data visualizations and how data are generated and used to make predictions (Wasson, Hansen, \& Netteland, 2016). However, it seems that teachers' preparation is not sufficient in the technological domain, as a report on Norwegian schools has noted (Søby, 2013).

With technological advances, new assessment opportunities arise (Dawson \& Siemens, 2014). More frequent feedback on learning progress can be provided, in which successful students receive confirmation on their skills and motivational boosts, and struggling students get early intervention and teachers' attention. Constant monitoring would provide formative potential for learning (Williams, 2014), as final exams could be replaced or complemented with other assessment measures. An overview of students' competence and knowledge can be useful for teachers forming teams for practical training and project-based learning. 
Well-planned curricula ensure smooth institutional work that complies with national educational requirements, providing better education quality. Teachers can incorporate feedback accumulated through LA into future learning content, thereby enhancing students' success (Siemens, 2013). For example, LA was used in an online healthcare administration program to better line up its curriculum with needed professional competencies, as well as change course objectives and summative learning assessments' structures (Ozdemir \& Stebbins, 2015) and predict students' future course selections from identifiable and non-identifiable student data (Ognjanovic, Gasevic, \& Dawson, 2016).

LA could be used as a time- and money-saving means to facilitate teachers' professional development without them being away from the classroom. Teachers can investigate the efficacy of various teaching methods, tools, and approaches with different student groups (Hansen \& Wasson, 2016). However, the question remains whether time and financial investments spent on training teachers to analyze and interpret course data will pay off by improving teachers' instructional-design skills and leading to students' success. Many teachers can spot a struggling student early without any technology, and solutions to these struggles require teachers' personal approach and contact with the student. Teachers have many responsibilities and generally are overworked. Setting an additional requirement to analyze and interpret data may take time away from live face-to-face interactions with students, i.e., actual teaching.

\section{Student level}

Reflection is one of the most useful benefits that LA can provide to individual students. It can be used to analyze students' behavior in learning management systems, test results, and assignment completion, as well as provide an overview of current knowledge levels. Such tools are designed to support collaborations between students and help them trace challenges in group discussions 
(Van Leeuwen et al., 2014). LA tools can determine a student's standing based on class level or educational goals. Drachsler and Greller (2016) argue that "the focus of analytics should be put on self-reflection, rather than prediction or justification" (p. 7). LA can support self-regulated learning, as it provides personalized information and an opportunity to see immediate consequences of actions so that independent decisions can be made, e.g., trying again or asking for help. The importance of feedback is emphasized by Clow (2012), who argues that any effective LA application must end with interventions in the form of feedback by the program directly to the student or a teacher making personal contact with a student at risk. From a psychological perspective, work done by Bennett (2018) shows that students' engagement with dashboards is individual and connected to self-identity — not only as a matter of understanding. It can elicit various cognitive, emotional, and behavioral reactions. The author recommends allowing students to personalize dashboards, i.e., design them in a way that highlights each student's learning trajectory. Thus, embedding and supporting the use of dashboards can make a positive impact.

Personalization of students' learning paths has been suggested in recent years, e.g., providing opportunities for vocational students to choose individual study paces and trajectories by taking additional language and/or learning-skills courses, or increasing on-the-job training time (Juutilainen \& Räty, 2017). This general trend of individualizing study paths also can be scaffolded with the help of LA (Arnold \& Pistilli, 2012; Yarnall et al., 2016). For example, adaptations can be made based on online learning materials and on-the-job training suggestions according to students' preferences and personal study goals. In Krauss, Merceron, An, Zwicklbauer, \& Arbanowski's (2016) study, an LA application evaluates vocational students' knowledge based on assessments and behavior in learning-management systems and 
recommends further learning materials or suggests revising certain topics. How effective personalization is and whether it improves educational outcomes depend on learning materials, motivation, study design, and other factors. Evidence suggests that seeing personalized data on the dashboard can increase motivation (Bennett, 2018), and personalized learning can lead to slightly better grades (Arnold \& Pistilli, 2012; Yarnall et al., 2016; Jayaprakash, Moody, Lauria, Regan, \& Baron, 2014).

The most popular way to apply LA in educational settings has been to examine log data to visualize learning trajectories and predict the success or failure for course completion (Nistor, Derntl, \& Klamma, 2015). However, LA is only useful if it makes reliable predictions (Tempelaar, Rienties, \& Giesbers, 2015) early in the academic year, as late predictions do not require sophisticated software and can be made through teacher-administered tests. Predictive models alone do not influence retention or course completion. Information about predictions must be combined with effective intervention strategies to help struggling students reach educational goals (Jayaprakash et al., 2014).

For instance, Arnold \& Pistilli (2012) describe how at Purdue University, students received feedback about their academic progress in colors-coded rankings. Feedback was generated from combined information on students' interactions with the learning-management system, previous academic history, and socioeconomic data. Interventions comprised automatically generated e-mails, text messages, referrals to academic advisors, or face-to-face meetings with supervisors and made a slight impact on grades and retention. Students who could use LA earlier and, in more courses, continued studies in higher numbers (Arnold \& Pistilli, 2012). This shows that LA feedback need not be sophisticated to be effective. A computergenerated e-mail letting students know that they are at risk of failing is effective enough to elicit 
slight changes in grades (Jayaprakash et al., 2014). As vocational schools often are lacking in financial and personal resources to administer individual interventions to large groups of at-risk students, such LA interventions could be simple, yet effective.

Students' young ages must be considered when designing learning technologies for VET. Retention is found to be highest among community-college students taking blended (online and on-campus) classes and lowest among those taking online courses, although the difference was small (James, Swan, \& Daston, 2016). It also was found that older students taking online courses persevere more than younger students. This is an important finding for the sector, as many students enter VET straight after basic education (Juutilainen \& Räty, 2017). Independent studying, even if guided by LA recommendations, requires well-developed learning skills and is challenging for many.

Successful application of LA must be appealing. Students named support for planning and organization of learning processes, self-assessments, adaptive recommendations, and personalized analyses of learning activities as the most important aspects (Schumacher \& Ifenthaler, 2016). Attractive design, ability to interact with other users, and social media support are also suggested (Firat, 2016).

\section{LA use in different VET contexts}

Cooperation between vocational institutions and the working world may vary in different countries. The European Union regards this cooperation as a priority and promotes work-based learning in all its forms, with special attention given to apprenticeships (European Commission, 2015). Cooperation between VET institutions and working life is crucial for students' education, as well as their future job opportunities. Cooperation can take place at organizational, 
professional, student, and teacher levels, and also can lead to developing education practices (Kettunen, 2013). Workplace training needs to be monitored and mediated to help students learn transferable and assessable competencies (Suursalmi, 2017; Isacsson, 2013). This provides opportunities for LA to support the transfer of knowledge between classroom and workplace learning. For instance, LA could be used as part of apprenticeship training, providing individual feedback and cumulative data for human-resource purposes, as well as develop cooperation between VET institutions and workplaces. However, authentic workplace contexts in VET have generated scant scientific research, and LA applications that focus on this type of learning are rare (Ruiz-Calleja et al., 2017).

Being closely related to the world of work, VET's challenge is to prepare future employees so that they can utilize technologies. Personalized and collaborative learning models through social media and virtual learning environments - as well as various tools such as Google, Moodle, social network platforms, virtual meeting tools, wikis, blogs, and podcasts — are used to develop competencies needed in the knowledge society (Aarreniemi-Jokipelto, 2013). Gamification, serious games, and mobile learning also can be used in VET to practice identical or similar elements of different VET contexts. However, a question remains: What kind of data could be gathered from these serious games and how could it be used to stimulate the learning process, as artisan fields are practiced in numerous ways, with different competencies being acquired in the process?

Some trials have experimented with using mobile learning as a student support during workplace practice in VET (Wilke, Kowalewski, Magenheim, \& Margaritis, 2015). Although this proposal focuses on the practical aspects of workplace training, it lacks details on whether data could be used further for LA. 
One of the most detailed scientific case studies comes from Norway, where researchers aimed to visualize competencies for firefighters (Hansen et al., 2016). To become a professional firefighter, one must be physically fit, as well as take a variety of courses, including first aid and how to work with heavy machinery. Also, every individual team needs members with specific qualifications. The fire department must review qualifications regularly, keeping in mind retirement plans and injuries to maintain a sufficient number of employees.

The project aims to integrate formal qualifications with evaluations from real-life work situations, visualize students and workers' competencies and help management determine individual, group, and organizational needs (Hansen et al., 2016).

\section{Central ethical themes for successful LA implementation}

During the review process, it was noted that ethics are an integral part of LA in education. Four articles discuss the topic of ethical LA use in the context of the government (1), institution (4), and teacher (1) perspectives. It seems that an individual student as a data subject is not viewed as being able to influence ethical data handling. This topic could draw researchers' attention in the future. Articles on ethics in LA adopted a broad approach and did not direct their proposals to higher education specifically, suggesting that an ethical LA framework could be used in any educational settings. Furthermore, we provide a short overview on ethics in LA.

To implement LA in an educational institution, ethical topics should be considered in advance. Anecdotal cases from InBloom in the US and Snippet (Drachsler \& Greller, 2016) in the Netherlands illustrate that data-handling concerns can sabotage LA initiatives. Data availability also raises temptations for unethical conduct. A case in the US shows how college administrators used students' mental-health data to pressure students to leave college to improve 
the college's ranking (Yonette \& McPhate, 2016). To protect students, LA practices must be defined and regulated at the national and institutional levels. Many scientists have proposed and discussed ideas on how this should be done (Drachsler \& Greller, 2016; Pardo \& Siemens, 2014; Rodríguez-Triana, Martínez-Monés, \& Villagrá-Sobrino, 2016; Sclater, 2016; Slade \& Prinsloo, 2013). Most agree that transparency and consent are crucial LA aspects. All stakeholders should understand data sources' purpose, access, usage boundaries, and interpretation possibilities (Sclater, 2016). Most publications also agree that students should have a right to leave or refuse to participate in LA, as well as change their minds later, and that any negative consequences for doing so should be avoided or clearly explained to students (Drachsler \& Greller, 2016; Pardo \& Siemens, 2014; Sclater, 2016; Slade \& Prinsloo, 2013). These questions become even more relevant when it comes to transparency and consent in VET, in which some students are vulnerable, e.g., underage immigrants with serious language barriers, students with learning disabilities, or students with less economic power. However, if LA is used in everyday education, opting out or refusing to participate may not be possible or even reasonable (Sclater, 2016). This may elicit unexpected consequences, as students were observed withdrawing from courses using LA, fearing academic and financial penalties (Jayaprakash et al., 2014). Likewise, this may lead to unfavorable consequences for financially struggling students or other vulnerable groups who may be discouraged from pursuing education.

Ethical LA usage must be ensured by law because "issues related to privacy, ethics, and data protection are $[\ldots]$ complex issues, students and teachers may never entirely understand, and thus protection must be provided by policy" (Wasson, Hansen \& Netteland, 2016, p. 3). Policy makers need to ensure LA predictions' validity and proper functioning for a department, institution, or person (Pardo \& Siemens, 2014; Bienkowski et al., 2012). 
The same ethical principles also should be applied with respect to smaller teacher-led innovations in class (Rodríguez-Triana et al., 2016). The teacher must take responsibility to observe ethical standards and consider possible consequences for class dynamics. This is important when considering smaller schools and younger students in VET.

Greller \& Drachsler (2012) are raising concerns that if LA is misused, it can become an instrument used to control students and teachers. Segregation, peer pressure, and conformity would be reinforced, instead of personalization and individualization (Greller \& Drachsler, 2012). This is relevant in VET, in which diversity is great and possibilities for transferring the learning process online differ. Situations in which some students' groups are placed in a lessfavorable position than others, without access to services such as counselling interventions, could occur.

\section{Conclusions}

Extant literature on LA in education is polarized. Many possibilities exist to use educational data in teaching and learning — following students' footsteps, visualizing learning data, providing immediate and personalized feedback, and providing data for management decisions. LA also can provide possibilities for reflection that spans all educational levels. VET could benefit from applications and methods that allow for tracking and evaluation of student performance in onthe-job training as well as incorporating competencies from various educational settings. However, extant LA implementation literature in educational institutions is scant, focusing on higher education and dominated by private vendors. A research gap exists concerning LA possibilities for combining workplace and in-class learning, and ethical data use is a big concern. The most popular application is identifying students at risk and possible dropouts, which are pressing issues in VET, and more empirical research is needed regarding various student groups 
and possible interventions. Efforts have been made to discuss LA applications on a national level. As applications are scant and used for only a short time, reliably measuring LA effects on learning and teaching is problematic, with little solid evidence. Technical challenges and ethical issues must be solved before LA can be effective and useful for individuals and educational institutions.

This study's limitations are related to differences in educational systems across Europe and the world. VET may have slightly varying objectives and structures in different countries, so generalizing should be done with care. In the literature section, we used the term vocational education, but terms such as further education and continuing education could be used to describe VET in other countries. Adding these terms to the search process would widen this field's review scope. For the coding of intended target audiences, the definition of the target audiences in the original publication may not provide information about all possible audiences. More in-depth knowledge of each context could have changed some of the interpretations. Based on the systematic literature review, we make three central recommendations for future LA use and development:

\section{LA tools development for VET}

Development opportunities exist for LA tools suitable for VET, combining and visualizing data from learning in the workplace and learning in the classroom. Educational technology and LA tools are developed on a small scale, i.e., the field is scattered, the tools expire quickly, and it is difficult to combine information from various sources and unify the data. LA could be used in assessment support to help teachers and workplace supervisors recognize students and workers' needs and skills to make learning progress more visible in VET. 


\section{Understanding current LA limitations for VET}

It is important to understand LA and other technology's limitations and calibrate them to serve suitable educational tasks. Technical skills or more routine tasks can benefit from LA, due to getting feedback on skills development through repetition. More research is needed to understand how LA can develop and support students' reflections, motivations, and learning skills, such as self-regulation skills and time management, as well as promote higher-order thinking skills and in-depth learning in various VET settings.

\section{Educating stakeholders on ethical data handling and LA use}

Teachers, school administrators, and other parties need support and training on ethical and technological data-handling procedures. All parties need to understand how data are generated and used to make predictions. Awareness of the technology's limitations and procedures for dealing with sensitive issues need to be established and given a high priority in education.

\section{References}

References marked with * were included in the analysis

Aarreniemi-Jokipelto, P. (2013). Personalized and collaborative learning models through social media. In: K. Aaltonen, A. Isacsson, J. Laukia, \& L. Vanhanen-Nuutinen (Eds), Practical skills, education and development: Vocational education and training in Finland (pp. 159-176). Vantaa, Finland: Haaga-Helia University of Applied Sciences.

(*)Agudo-Peregrina, Á. F., Iglesias-Pradas, S., Conde-González, M. Á., \& Hernández García, Á. (2014). Can we predict success from log data in VLEs? Classification of interactions for learning analytics and their relation with performance in VLE-supported F2F and online learning. Computers in Human Behavior, 31, 542-550. 
(*)Arnold, K. E., \& Pistilli, M. D. (2012). Course signals at Purdue: Using learning analytics to increase student success. Proceedings of the 2nd International Conference on Learning Analytics and Knowledge (pp. 267-270). New York, NY: ACM.

(*)Avella, T. J., Kerbritchi, M., Nunn, G. S., \& Kanai, T. (2016). Learning analytics methods, benefits, and challenges in higher education: A systematic literature review. Online Learning Journal, 20(2), 13-29.

(*)Bannert, M., Molenaar I., Azevedo, R., Järvelä, S., \& Gasevic, D. (2017). Relevance of learning analytics to measure and support students' learning in adaptive educational technologies. In: $L A K$ ' 17 Proceedings of the Seventh International Learning Analytics \& Knowledge Conference (pp. 568-569). New York, NY: ACM.

Bennett, L. (2018). Students' learning responses to receiving dashboard data. (Research report, 2018, January). Retrieved from Society for Research Into Higher Education website: https://www.srhe.ac.uk/downloads/reports-2016/LizBennet-scoping2016.pdf

(*)Bienkowski, M., Feng, M., \& Means, B. (2012). Enhancing teaching and learning through educational data mining and learning analytics: An issue brief. Washington, DC: US Department of Education.

(*)Boulden, D. C. (2015). Learning analytics: Potential for enhancing school library programs. Knowledge Quest, 44(2), 54-59. Retrieved from http://files.eric.ed.gov/fulltext/EJ1079823.pdf

(*)Buckingham, S. S., \& Ferguson, R. (2012). Social learning analytics. Educational Technology \& Society, 15(3), 3-26.

(*)Bull, S. (2016). Negotiated learner modelling to maintain today's learner models. $\underline{\text { Research }}$ and Practice in Technology Enhanced Learning, 11(10), 1-29.

(*)Bull, S., \& Kay, J. (2016). SMILI: A framework for interfaces to learning data in open learner models, learning analytics and related field. International Journal of Artificial Intelligence in Education, 26(1), 293-331.

(*)Calvet Liñán, L., \& Juan Pérez, Á.A. (2015). Educational data mining and learning analytics: differences, similarities, and time evolution. International Journal of Educational Technology in Higher Education, 12(ㄱ), 98-112. 
(*)Chatti, M. A., Lukarov, V., Thüs, H., Muslim, A., Yousef, A. M. F., Wahid, U., Greven, C., Chakrabarti, A., \& Schroeder, U. (2014). Learning analytics: Challenges and future research directions. E Learning and Education, 10.

(*)Clarke, N., \& Nellson, K. (2013). Perspectives on learning analytics: Issues and challenges. Observations from Shane Dawson and Phil Long. International Journal of The First Year in Higher Education, 4(1), 1-8.

Clow, D. (2012). The learning analytics cycle: Closing the loop effectively. In: Proceedings of the 2nd International Conference on Learning Analytics and Knowledge - LAK '12, (pp. 134-137). New York, NY: ACM.

(*)Conejo, R., Guzmán, E., \& Trella, M. (2016). The SIETTE automatic assessment environment. International Journal of Artificial Intelligence in Education, 26(1), 270292.

Cooper, H., \& Hedges, L. V. (2009). Research synthesis as a scientific process. Handbook of Research Synthesis and Meta-Analysis, 3-17.

(*)Cope, B., \& Kalantzis, M. (2015). Interpreting evidence-of-learning: Educational research in the era of big data. Open Review of Educational Research, 2(1), 218-239.

(*)Dawson, S., \& Siemens, G. (2014). Analytics to literacies: The development of a learning analytics framework for multiliteracies assessment. International Review of Research in Open and Distance Learning, 15(4), 284-305.

(*)Drachsler, H., \& Greller, W. (2012). The pulse of learning analytics understandings and expectations from the stakeholders. Proceedings of the 2nd International Conference on Learning Analytics and Knowledge (pp. 120-129). New York, NY: ACM.

(*)Drachsler, H., \& Greller, W. (2016). Privacy and analytics - it's a DELICATE issue: A checklist for trusted learning analytics. Proceedings of the 6th Learning Analytics and Knowledge Conference (LAK'16), April 25-19, 2016, Edinburgh, UK, (pp. 89-98). New York, NY: ACM.

(*)Elouazizi, N. (2014). Critical factors in data governance for learning analytics. Journal of Learning Analytics, 1(3), 211-222.

(*)Essa, A., \& Ayad, H. (2012). Improving student success using predictive models and data visualizations. Research in Learning Technology, 20. 
European Commission (2012). Vocational education and training for better skills, growth and jobs. Accompanying the document Communication from the commission rethinking Education: Investing in skills for better socio-economic outcomes. Strasbourg. https://eur-lex.europa.eu/legal-content/EN/ALL/?uri=CELEX:52012SC0375

European Commission (2015). Riga Conclusions 2015 on a new set of medium-term deliverables in the field of VET for the period 2015-2020. Riga. http://www.izm.gov.lv/images/RigaConclusions_2015.pdf

(*)Ferguson, R. (2012). Learning analytics: Drivers, developments, and challenges. International Journal of Technology Enhanced Learning, 4(5/6), 304-317.

Finnish National Agency for Education (2017). Hallituksen esitys laiksi ammatillisesta koulutuksesta ja eräiksi siihen liittyviksi laeiksi [Government proposal on vocational training and related acts]. HE 39/2017. Retrieved from http://minedu.fi/paatos?decisionId=0900908f8052b569

(*)Firat, M. (2016). Determining the effects of LMS learning behaviors on academic achievement in a learning analytic perspective. Journal of Information Technology Education: Research, 15, 75-87. Retrieved from http://www.jite.org/documents/Vol15/JITEv15ResearchP075-087Firat1928.pdf

(*)Gašević, D., Dawson, S., \& Siemens, G. (2015). Let's not forget: Learning analytics are about learning. TechTrends, 59(1), 64-71.

(*)Geri, N., Winer, A. \& Zaks, B. (2017). A learning analytics approach for evaluating the impact of online video lectures on the attention span of students. Interdisciplinary Journal of e-Skills and Lifelong Learning, 13, 215-228.

Giles, M., Le, A. T., Allan, M., Lees, C., Larsen A.-C., \& Bennett, L. (2007). The role of education and training in prison to work transitions. In: S. Dawe (Ed.), Vocational education and training for adult prisoners and offenders in Australia (pp. 67-77). Adelaide, Australia: NCVER

(*)Greller, W., \& Drachsler, H. (2012). Translating learning into numbers: A generic framework for learning analytics. Journal of Educational Technology \& Society, 15(3), 42-57. Retrieved from http://www.jstor.org/stable/jeductechsoci.15.3.42

(*)Hansen, C. J., Netteland, G., \& Wasson, B. (2016). Learning analytics and open learning modelling for professional competence development of firefighters and future healthcare 
leaders. CEUR Workshop Proceedings, 1601, 87-90. Retrieved from http://nbnresolving.de/urn:nbn:de:0074-1601-3

(*)Hansen, C. J., \& Wasson, B. (2016). Teacher inquiry into student learning: The TISL heart model and method for use in teachers' professional development. Nordic Journal of Digital Literacy, 11(1), 24-49.

(*)Heffernan, N. T., Ostrow, K. S., Kelly, K., Selent, D., Van Inwegen, E. D., Xiong, X., \& Williams, J.J. (2016). The future of adaptive learning: Does the crowd hold the key? International Journal of Artificial Intelligence in Education, 26, 615-644.

(*)Hernández-García, A., González-González, I., Jiménez Zarco, A. I., \& Chaparro-Peláez, J. (2016). Visualizations of online course interactions for social network learning analytics. International Journal of Emerging Technologies in Learning, 11(7), 6-15.

Honkonen, K. (2017). Apprenticeship education. In: J. Laukia, A. Isacsson, \& P.-K. Juutilainen (Eds.), Vocational education with a Finnish touch (pp. 54-64). Helsinki, Finland: HaagaHelia University of Applied Sciences.

(*)Ihantola, P., Vihavainen, A., Ahadi, A., Butler, M., Börstler, J., Edwards, S. H., ... Toll, D. (2015). Educational data mining and learning analytics in programming: Literature review and case studies. In: Proceedings of the 2015 ITiCSE on Working Group Reports (pp. 41-63). New York, NY: ACM.

Isacsson, A. (2013). Work-integrated learning in Finland - a conceptual overview. In: K. Aaltonen, A. Isacsson, J. Laukia, \& L. Vanhanen-Nuutinen (Eds), Practical skills, education and development: Vocational education and training in Finland (pp. 145-154). Vantaa, Finland: Haaga-Helia University of Applied Sciences.

Isacsson, A. (2017). Integrative learning in education and expertise. In: J. Laukia, A. Isacsson, \& P.-K. Juutilainen (Eds.), Vocational education with a Finnish touch (pp. 44-53). Helsinki, Finland: Haaga-Helia University of Applied Sciences.

James, S., Swan, K., \& Daston, C. (2016). Retention, progression and the taking of online courses. Journal of Asynchronous Learning Network, 20(2), 75-96.

(*)Jayaprakash, S. M., Moody, E. W., Lauria, E. J. M., Regan, J. R., \& Baron, J. D. (2014). Early alert of academically at-risk students: An open source analytics initiative. Journal of Learning Analytics, 1(1), 6-47. 
Juutilainen, P.-K., \& Räty, K. (2017). Educational support and guidance counselling in Finnish vocational education. In: J. Laukia, A. Isacsson, \& P.-K. Juutilainen (Eds.), Vocational education with a Finnish touch (pp. 75-87). Helsinki, Finland: Haaga-Helia University of Applied Sciences.

Kettunen, J. (2013). Bridging the gap between learning inside and outside of higher education institutions. In: K. Aaltonen, A. Isacsson, J. Laukia, \& LVanhanen-Nuutinen (Eds.), Practical skills, education and development: Vocational education and training in Finland (pp. 51-63). Vantaa, Finland: Haaga-Helia University of Applied Sciences.

(*)Khousa, E. A., Atif, Y., \& Masud, M. M. (2015). A social learning analytics approach to cognitive apprenticeship. Smart Learning Environments, 2(14).

(*)Krauss, C., Merceron, A., An, T.-S., Zwicklbauer, M., \& Arbanowski, S. (2016). The smart learning approach: A mobile learning companion application. eLmL Conference Proceedings, 8, 13-16. Retrieved from https://www.researchgate.net/publication/303437603

(*)Larusson, J. A., \& White, B. (2014). Introduction. In: J. A. Larusson \& B. White (Eds.), Learning analytics: From research to practice (pp. 1-14). New York: Springer-Verlag. Laukia, J. (2017). From the shadows to brightness: The development of vocational education in Finland. In: J. Laukia, A. Isacsson, \& P.-K. Juutilainen (Eds.), Vocational education with a Finnish touch (pp. 8-22). Helsinki, Finland: Haaga-Helia University of Applied Sciences.

(*)Lavigne, G., Gutiérrez Ruiz, G., McAnally-Salas, L., \& Sandoval, J. O. (2015). Log analysis in a virtual learning environment for engineering students. International Journal of Educational Technology in Higher Education, 12(3), 113-128.

(*)Leitner, P., Khalil, M., \& Ebner, M., (2017). Learning analytics in higher education: A literature review. In: A. Peña-Ayala (Ed.). Studies in systems, decision and control: Vol. 94. Learning analytics: Fundaments, applications, and trends (pp. 1-23). New York: Springer.

(*)Macfadyen, L. P., \& Dawson, S. (2012). Numbers are not enough: Why e-learning analytics failed to inform an institutional strategic plan. Educational Technology and Society, 15(3), 149-163. 
(*)Meadows, C., Soper, K., Cullen, R., Wasiuk, C., McAllister-Gibson, C., \& Danby, P. (2016). Shaping the future of learning using the student voice: We're listening but are we hearing clearly? Research in Learning Technology, 24.

Moher, D., Liberati, A., Tetzlaff, J, Altman, D. G, \& The PRISMA group (2009). Preferred reporting items for systematic reviews and meta-analyses: The PRISMA statement. PLOS Medicine, 6(7), e1000097.

(*)Mouri, K., \& Ogata, H. (2015). Ubiquitous learning analytics in the real-world language learning. Smart Learning Environments, 2(15).

(*)Nistor, N., Derntl, M., \& Klamma, R. (2015). Learning analytics: Trends and issues of the empirical research of the years 2011-2014. In: G. Conole, T. Klobučar, C. Rensing, J. Konert, \& É. Lavoué (Eds.). Information Systems and Applications, Internet/Web, and HCI: Vol. 9307. Design for teaching and learning in a networked world (pp. 453-459). New York: Springer.

(*)Ognjanovic, I., Gasevic, D., \& Dawson, S. (2016). Using non-identifiable data to predict student course selections. Internet and Higher Education, 29, 49-62.

Ozdemir, D. \&Stebbins, C. (2015). Curriculum Mapping for the Utilization of a Learning Analytics System in an Online Competency-Based Master of Health Care Administration Program : A Case Study. The Journal of Health Administration Education,32(4), 543563.

(*)O’Riordan, T., Millard, D. E., \& Schulz, J. (2016). How should we measure online learning activity? Research in Learning Technology, 24.

(*)Papamitsiou, Z., \& Economides, A. A. (2014). Learning analytics and educational data mining in practice: A systematic literature review of empirical evidence. Educational Technology \& Society, 17(4), 49-64.

(*)Papamitsiou, Z., \& Economides, A. A. (2015). Temporal learning analytics visualizations for increasing awareness during assessment. International Journal of Educational Technology in Higher Education, 12(3), 129-147.

(*)Pardo, A., \& Siemens, G. (2014). Ethical and privacy principles for learning analytics. British Journal of Educational Technology, 45(3), 438-450.

(*)Price, J. K. (2015). Transforming learning for the smart learning environment: Lessons learned from the Intel education initiatives. Smart Learning Environments, 2(1), 16. 
Official Statistics of Finland (2017). Discontinuation of education [e-publication]. Helsinki:

Statistics Finland. Retrieved from http://www.stat.fi/til/kkesk/

(*)Rabelo, T., Lama, M., Amorim, M., \& Vidal, J. (2015). SmartLAK: A big data architecture for supporting learning analytics services. In: Frontiers in Education Proceedings (pp. 781-785). Texas, TX: IEEE.

(*)Reimann, P. (2016). Connecting learning analytics with learning research: The role of designbased research. Learning: Research and Practice, 2(2), 130-142.

(*)Rodríguez-Triana, M. J., Martínez-Monés, A., \& Villagrá-Sobrino, S. (2016). Learning analytics in small-scale teacher-led innovations: Ethical and data privacy issues. Journal of Learning Analytics, 3(1), 43-65.

Ruiz-Calleja, A., Prieto, L. P., Ley, T., Rodriguez-Triana, J. M., \& Dennerlein, S. (2017).

Learning analytics for professional and workplace learning: A literature review. In: É.

Lavoué, H. Drachsler, K. Verbert, \& M. Perez-Snagustin (Eds.), Data driven approaches in digital education. 12th European conference on technology enhanced learning, ECTEL (pp. 164-178). New York: Springer.

Saranpää, M. (2017). Quality assurance in Finnish vocational education. In: J. Laukia, A.

Isacsson, \& P.-K. Juutilainen (Eds.), Vocational education with a Finnish touch (pp. 8997). Helsinki, Finland: Haaga-Helia University of Applied Sciences.

Schumacher, C. \& Ifenthaler, D. (2016). Features students really expect from learning analytics. In: Proceedings 13th International Conference on Cognition and Exploratory Learning in Digital Age (CELDA 2016), 3. (pp. 67-76). New York: Curran.

(*)Sclater, N. (2016). Developing a code of practice for learning analytics. Journal of Learning Analytics, 3(1), 16-42.

Siemens, G. (2013). Learning analytics: The emergence of a discipline. American Behavioral Scientist, 57(10), 1380-1400.

(*)Siemens, G., \& Baker, T. (2014). Educational data mining and learning analytics. In K. R. Sawyer (Ed.), The Cambridge handbook of the learning sciences (pp. 253-272). New York: Cambridge University Press.

(*)Slade, S., \& Prinsloo, P. (2013). Learning analytics: Ethical issues and dilemmas. American Behavioral Scientist, 57(10), 1510-1529. 
Suursalmi, P. (2017). Vocational education and training in collaboration with the world of work. In: J. Laukia, A. Isacsson, \& P.-K. Juutilainen (Eds.), Vocational education with a Finnish touch (pp. 33-43). Helsinki, Finland: Haaga-Helia University of Applied Sciences.

Søby, M. (2013). Horizon: Technology outlook for Norwegian schools mapping and analyzing prospective technologies for learning. Nordic Journal of Digital Literacy, 8(4), 187-190. Retrieved from https://www.idunn.no/dk/2013/04/horizon_technology_outlook_for_norwegian_schools\#

(*)Tempelaar, D. T., Rienties, B., \& Giesbers, B. (2015). In search for the most informative data for feedback generation: Learning analytics in a data-rich context. Computers in Human Behavior, 47, 157-167.

(*)Van Leeuwen, A., Janssen, J., Erkens, G., \& Brekelmans, M. (2014). Supporting teachers in guiding collaborating students: Effects of learning analytics in CSCL. Computers \& Education, 79, 28-39.

(*)Wasson, B., Hansen, C., \& Netteland, G. (2016). Data literacy and use for learning when using learning analytics for learners. CEUR Workshop Proceedings, 1596, 38-41. Retrieved from http://ceur-ws.org/Vol-1596/paper6.pdf

(*)Wilke, A., Kowalewski, M., Magenheim, J., \& Margaritis, M. (2015). Facing the upcoming challenges in vocational training with mobile learning. In: A. Brodnik \& C. Lewin (Eds.), IFIP TC3 Working Conference: A New Culture of Learning: Computing and Next Generations Proceedings, (pp. 405-406), Vilnius, Lithuania, July 2015. Retrieved from http://www.ifip2015.mii.vu.lt

Williams, P. (2014). Squaring the circle: A new alternative to alternative-assessment. Teaching in Higher Education, 9(5), 1-13.

(*)Williamson, B. (2015). Algorithmic skin: Health-tracking technologies, personal analytics and the biopedagogies of digitalized health and physical education. Sport Education and Society, 20(1), 133-151.

(*)Williamson, B. (2016a). Digital education governance: Data visualization, predictive analytics, and "real-time" policy instruments. Journal of Education Policy, 31(2), 123 141. 
(*)Williamson, B. (2016b). Governing software: Networks, databases, and algorithmic power in the digital governance of public education. Learning, Media and Technology, 40(1), 83105.

(*)Yarnall, L., Means, B., \& Wetzel, T. (2016). Lessons learned from early implementations of adaptive courseware (Report 21987/22997). Menlo Park, CA: SRI International.

Retrieved from https://library.educause.edu/resources/2016/6/lessons-learned-from-earlyimplementations-of-adaptive-courseware

Yonette, J., \& McPhate, M. (2016, February 29). Mount St. Mary's president quits after firings seen as retaliatory. New York Times. Retrieved from https://www.nytimes.com/2016/03/02/us/simon-newman-resigns-as-president-of-mountst-marys.html?_r=0

(*)You, J. W. (2016). Identifying significant indicators using LMS data to predict course achievement in online learning. Internet and Higher Education, 29, 23-30. 